\title{
Role of mitomycin C in pterygium surgery
}

\author{
P S Mahar, G E Nwokora
}

\begin{abstract}
Mitomycin $\mathbf{C}$ in the form of eye drops in a concentration of $0.4 \mathrm{mg} / \mathrm{ml}(0.04 \%)$ was used as adjunctive treatment for primary and recurrent pterygium after surgical excision. The study was concurrent in nature and consisted of 32 pterygia in 30 patients and was done over a period of 36 months. The object was to observe the effect of mitomycin $\mathrm{C}$ drops on pterygium recurrence after surgical excision. Fifteen eyes of 15 patients were treated with 'bare sclera technique' for pterygium excision. Nine patients showed recurrence occurring within first 6 months of surgery. On the other hand 17 eyes of 15 patients after bare sclera pterygium excision received mitomycin $0.4 \mathrm{mg} / \mathrm{ml}(0.04 \%)$ eye drops four times a day for 2 weeks from first postoperative day. There was no recurrence of pterygium in this group. Follow up time for these cases ranged from 13-19 months. (Brf Ophthalmol 1993; 77: 433-435)
\end{abstract}

Pterygium occurs all over the world but it is more common in subtropical and tropical areas. It is one of the common corneal disorders seen in Saudi Arabia. The stimulus which causes a pterygium to grow is excessive exposure to ultraviolet sunlight. Other agents that give rise to chronic irritation of the conjunctiva such as air pollution, dust, and wind have also been mentioned as determining factors. ${ }^{12}$

Treatment of choice for pterygium is surgical excision. However, the recurrence rate of pterygium after excision is quite high (30$50 \%)^{3-6}$ unless something is done at the time of excision.

The use of postoperative $\beta$ irradiation $^{7-11}$ has been reported to lower the incidence of recurrence to less than $5 \%$ but has led to further complications such as scleral ulceration and cataract formation. It also requires special centres and management for referring such patients.

Argon laser has been used to control very early blood vessel growth in the sclera and limbus to prevent pterygium recurrence following surgery. ${ }^{12}$

Though in the past many workers have shown good results with use of topical thiotepa (triethylene thiophosphoramide), ${ }^{13-16}$ a radiomimetic alkylating agent, one of the problems that occurs in darkly pigmented patients is depigmentation of the lids.

Conjunctival autograft transplantation has been used successfully by some workers ${ }^{17}{ }^{18}$ after pterygium excision to reduce the incidence of recurrence. But our local experience with free conjunctival grafts from the superotemporal bulbar conjunctiva of the same eye to resurface the exposed sclera has been disappointing (ongoing study). This also requires special equipment and is carried out under retrobulbar anaesthetic block, making patients vulnerable to complications associated with such procedures.

Encouraged by the results shown by Japanese and other workers, ${ }^{19-21}$ we undertook this concurrent study of mitomycin C $0.4 \mathrm{mg} / \mathrm{ml}(0.04 \%)$ drops used four times a day from first postoperative day for 2 weeks after pterygium excision by the bare sclera technique to determine its effect on pterygium recurrence. To the best of our knowledge this is the first study to be published from a country where pterygium is such an endemic problem.

\section{Materials and methods}

Patients attending the outpatient clinic with pterygium requiring surgery were allocated to two groups at random.

\section{GROUP I}

Patients in this group were operated on by the bare sclera technique. After preparing and draping the eye in normal sterile fashion, the lids were opened using a rigid eye speculum. Surface anaesthesia was achieved with $1 \%$ amethocaine drops. Lignocaine, $0.2 \mathrm{ml}$ of a $2 \%$ solution, with $1: 100000$ adrenaline was injected into the pterygium to elevate it into its attachment to the cornea. The head of the pterygium was grasped with St Martin's toothed forceps and excision was begun with a No 15 Baird-Parker blade about $0.5 \mathrm{~mm}$ ahead of the pterygium and carried down clearly to the limbus. The conjunctiva and subconjunctival tissue were then cleaned over the sclera towards the insertion of the medial rectus muscle and triangular excision of the pterygium and conjunctiva was carried out. Haemostasis was assured with light bipolar cautery. No conjunctival sutures were used. Postoperatively patients received Maxitrol ointment 3-4 times a day for 3-4 weeks. Surgery was carried out under an operating microscope.

\section{GROUP II}

Patients in this group were also operated on by the bare sclera technique, but postoperatively they received mitomycin C eye drops $0.4 \mathrm{mg} / \mathrm{ml}$ $(0.04 \%)$ one drop four times a day for 2 weeks along with Maxitrol eye ointment.

The division of patients was done at random irrespective of age and sex. All patients were local nationals, other nationalities were excluded from the study.

Fifteen patients were allocated to each group. The first surgical procedure was performed in August 1988 and last one in November 1990. Total follow up time was from 3 months to 36 
months. All patients were examined post- operatively took place, or if significant operatively at 1 week, 2 weeks, 1 month, and conjunctival vascularisation causing cosmetic later at 2 to 3 month intervals.

blemish occurred.

Recurrence was considered if fibrovascular All patients were examined by slit-lamp growth of a similar nature to that present pre- biomicroscopy with charting of visual acuity pre

Table 1 Series of patients treated with the bare sclera technique only

\begin{tabular}{|c|c|c|c|c|c|c|c|c|c|c|}
\hline \multirow[b]{2}{*}{ No } & \multirow[b]{2}{*}{ Age } & \multirow[b]{2}{*}{ Sex } & \multirow[b]{2}{*}{ Eye } & \multicolumn{2}{|l|}{ Preop data } & \multirow[b]{2}{*}{ Procedure } & \multicolumn{2}{|c|}{ Postop data } & \multirow[b]{2}{*}{ Recurrence } & \multirow{2}{*}{$\begin{array}{l}\text { Follow up } \\
\text { (months) }\end{array}$} \\
\hline & & & & Nature & $V / A$ & & $V / A$ & Complications & & \\
\hline 1 & 48 & $\mathbf{M}$ & LE & Primary & $6 / 6$ & $\begin{array}{l}\text { Excision }+ \\
\text { postop Maxitrol }\end{array}$ & $6 / 6$ & Nil & No & 25 \\
\hline 2 & 32 & $\mathbf{M}$ & RE & Primary & $6 / 6$ & $\begin{array}{l}\text { Excision }+ \\
\text { postop Maxitrol }\end{array}$ & $6 / 6$ & Nil & Yes & $\begin{array}{l}17 \\
\text { (failed to } \\
\text { attend } \\
\text { in between) }\end{array}$ \\
\hline 3 & 50 & $\mathbf{M}$ & $\mathbf{R E}$ & Primary & $6 / 9$ & $\begin{array}{l}\text { Excision }+ \\
\text { postop Maxitrol }\end{array}$ & $6 / 9$ & Nil & Yes & 3 \\
\hline 4 & 50 & $\mathbf{M}$ & LE & Recurrent & $6 / 9$ & $\begin{array}{l}\text { Excision }+ \\
\text { postop Maxitrol }\end{array}$ & $6 / 9$ & Nil & Yes & 8 \\
\hline 5 & 35 & $\mathbf{M}$ & LE & Primary & $6 / 6$ & $\begin{array}{l}\text { Excision }+ \\
\text { postop Maxitrol }\end{array}$ & $6 / 6$ & Nil & Yes & 10 \\
\hline 6 & 50 & $\mathbf{M}$ & LE & Primary & $6 / 9$ & $\begin{array}{l}\text { Excision }+ \\
\text { postop Maxitrol }\end{array}$ & $6 / 9$ & Nil & Yes & 5 \\
\hline 7 & 45 & $\mathbf{M}$ & RE & Primary & $6 / 9$ & $\begin{array}{l}\text { Excision }+ \\
\text { postop Maxitrol }\end{array}$ & $6 / 9$ & Nil & Yes & 5 \\
\hline 8 & 46 & $\mathbf{M}$ & LE & Primary & $6 / 6$ & $\begin{array}{l}\text { Excision }+ \\
\text { postop Maxitrol }\end{array}$ & $6 / 6$ & Nil & Yes & 5 \\
\hline 9 & 36 & $\mathbf{M}$ & $\mathbf{R E}$ & Primary & $6 / 6$ & $\begin{array}{l}\text { Excision }+ \\
\text { postop Maxitrol }\end{array}$ & $6 / 6$ & $\begin{array}{l}\text { formation of } \\
\text { granulation } \\
\text { tissue excised } \\
\text { by } 6 / 12\end{array}$ & No & 30 \\
\hline 10 & 19 & $\mathbf{M}$ & LE & Primary & $6 / 6$ & $\begin{array}{l}\text { Excision }+ \\
\text { postop Maxitrol }\end{array}$ & $6 / 6$ & Nil & Yes & 3 \\
\hline 11 & 32 & $\mathbf{M}$ & LE & Primary & $6 / 6$ & $\begin{array}{l}\text { Excision }+ \\
\text { postop Maxitrol }\end{array}$ & $6 / 6$ & Nil & No & 21 \\
\hline 12 & 45 & $M$ & RE & Primary & $6 / 6$ & $\begin{array}{l}\text { Excision }+ \\
\text { postop Maxitrol }\end{array}$ & $6 / 6$ & Nil & No & 30 \\
\hline 13 & 30 & $\mathbf{M}$ & RE & Primary & $6 / 6$ & $\begin{array}{l}\text { Excision }+ \\
\text { postop Maxitrol }\end{array}$ & $6 / 6$ & Nil & No & 36 \\
\hline 14 & 40 & $\mathbf{M}$ & RE & Primary & $6 / 6$ & $\begin{array}{l}\text { Excision }+ \\
\text { postop Maxitrol }\end{array}$ & $6 / 6$ & Nil & No & 30 \\
\hline 15 & 45 & $\mathbf{M}$ & RE & Primary & $6 / 6$ & $\begin{array}{l}\text { Excision }+ \\
\text { postop Maxitrol }\end{array}$ & $6 / 6$ & Nil & Yes & 4 \\
\hline
\end{tabular}

Table 2 Series of patients receiving postoperative mitomycin

\begin{tabular}{|c|c|c|c|c|c|c|c|c|c|c|}
\hline \multirow[b]{2}{*}{ No } & \multirow[b]{2}{*}{ Age } & \multirow[b]{2}{*}{ Sex } & \multirow[b]{2}{*}{ Eye } & \multicolumn{2}{|l|}{ Preop data } & \multirow[b]{2}{*}{ Procedure } & \multicolumn{2}{|c|}{ Postop data } & \multirow[b]{2}{*}{ Recurrence } & \multirow{2}{*}{$\begin{array}{l}\text { Follow up } \\
\text { (months) }\end{array}$} \\
\hline & & & & Nature & $V / A$ & & $V / A$ & Complications & & \\
\hline 1 & 49 & $\mathbf{M}$ & BE & Recurrent & 6/6 BE & $\begin{array}{l}\text { Excision + } \\
\text { Maxitrol + } \\
\text { mitomycin }\end{array}$ & 6/6 BE & Nil & No & 19 \\
\hline 2 & 40 & $\mathbf{M}$ & LE & Recurrent & 6/6 LE & $\begin{array}{l}\text { Excision + } \\
\text { Maxitrol + } \\
\text { mitomycin }\end{array}$ & 6/6 LE & Nil & No & 17 \\
\hline 3 & 24 & $\mathbf{M}$ & LE & Recurrent & 6/6 LE & $\begin{array}{l}\text { Excision + } \\
\text { Maxitrol + } \\
\text { mitomycin }\end{array}$ & 6/6 LE & Nil & No & 13 \\
\hline 4 & 29 & $\mathbf{M}$ & LE & Primary & 6/6 LE & $\begin{array}{l}\text { Excision + } \\
\text { Maxitrol + } \\
\text { mitomycin }\end{array}$ & 6/6 LE & Nil & No & 14 \\
\hline 5 & 53 & $\mathbf{M}$ & BE & Primary & $6 / 6 \mathrm{BE}$ & $\begin{array}{l}\text { Excision + } \\
\text { Maxitrol + } \\
\text { mitomycin }\end{array}$ & 6/6 BE & Nil & No & 14 \\
\hline 6 & 25 & $\mathbf{M}$ & $\mathbf{R E}$ & Primary & 6/6 RE & $\begin{array}{l}\text { Excision + } \\
\text { Maxitrol + } \\
\text { mitomycin }\end{array}$ & $6 / 6 \mathrm{RE}$ & Nil & No & 19 \\
\hline 7 & 50 & $\mathbf{M}$ & $\mathbf{R E}$ & Primary & 6/6 RE & $\begin{array}{l}\text { Excision + } \\
\text { Maxitrol + } \\
\text { mitomycin }\end{array}$ & 6/6 RE & $\begin{array}{l}\text { Mitomycin } \\
\text { stopped after } \\
\text { l week }\end{array}$ & No & 16 \\
\hline 8 & 50 & $\mathbf{F}$ & RE & Primary & 6/12 RE & $\begin{array}{l}\text { Excision + } \\
\text { Maxitrol + } \\
\text { mitomycin }\end{array}$ & $6 / 12 \mathrm{RE}$ & Nil & No & 18 \\
\hline 9 & 50 & $\mathbf{M}$ & RE & Primary & 6/9 RE & $\begin{array}{l}\text { Excision + } \\
\text { Maxitrol + } \\
\text { mitomycin }\end{array}$ & 6/9 RE & Nil & No & 13 \\
\hline 10 & 25 & $\mathbf{M}$ & RE & Primary & 6/6 RE & $\begin{array}{l}\text { Excision + } \\
\text { Maxitrol + } \\
\text { mitomycin }\end{array}$ & 6/6 RE & Nil & No & 13 \\
\hline 11 & 41 & $\mathbf{M}$ & LE & Primary & 6/9 LE & $\begin{array}{l}\text { Excision + } \\
\text { Maxitrol + } \\
\text { mitomycin }\end{array}$ & 6/9 LE & Nil & No & 13 \\
\hline 12 & 37 & $\mathbf{F}$ & LE & Primary & 6/6 LE & $\begin{array}{l}\text { Excision + } \\
\text { Maxitrol + } \\
\text { mitomycin }\end{array}$ & 6/6 LE & Nil & No & 13 \\
\hline 13 & 34 & $\mathbf{M}$ & RE & Primary & 6/6 RE & $\begin{array}{l}\text { Excision + } \\
\text { Maxitrol + } \\
\text { mitomycin }\end{array}$ & 6/6 RE & Nil & No & 14 \\
\hline 14 & 31 & $\mathbf{M}$ & LE & Primary & 6/6 LE & $\begin{array}{l}\text { Excision + } \\
\text { Maxitrol + } \\
\text { mitomycin }\end{array}$ & 6/6 LE & Nil & No & 14 \\
\hline 15 & 38 & $\mathbf{M}$ & LE & Primary & 6/6 RE & $\begin{array}{l}\text { Excision + } \\
\text { Maxitrol + } \\
\text { mitomycin }\end{array}$ & 6/6 LE & Nil & No & 15 \\
\hline
\end{tabular}


and postoperatively. Mitomycin C eye drops $(0.4$ $\mathrm{mg} / \mathrm{ml}$ or $0.04 \%$ ) were prepared in a cytotoxic dispensing safety cabinet by dissolving the mitomycin vial in sterile water for injection and transferring it to a clear ophthalmic dropper. The drops were kept in the refrigerator and used within 2 weeks.

\section{Results}

In group I, 15 eyes of 15 patients were treated. All were men. Their age ranged from 19 years to 50 years (mean age 34 years). All patients had primary pterygia except one patient (case 4, Table 1) who had recurrent pterygium. All pterygia were located nasally. Out of 15 cases, nine patients had recurrence, seen as early as 3 months to as late as 10 months $(60 \%)$. One patient (case 2, Table 1) failed to attend the clinic for review but when seen 17 months after surgery showed recurrence of pterygium. He stated that recurrence occurred very soon after his surgery. Six patients who did not show any recurrence were followed for a minimum of 21 months to a maximum of 36 months.

In group II, 17 eyes of 15 patients were treated (Table 2). Thirteen patients were men and two women. Their ages ranged from 24 years to 53 years (mean age 38 years). All pterygia were located nasally. Three pterygia were of recurrent type, the remaining were of a primary nature. No patient showed any recurrence. The follow up period ranged from 13 months to 19 months. All patients were strictly advised not to use more than one drop of mitomycin $\mathrm{C}$ four times a day and to discontinue it after 2 weeks of use. Conjunctival infection was the most frequent complication seen in all these patients with delayed wound healing for 3-4 weeks. One of the patients (case 7, Table 2) stopped the mitomycin $C$ drops after 1 week of use as the eye was irritable. No patient revealed any corneal changes, scleral changes, or anterior chamber reaction. No late changes were seen in these patients.

\section{Discussion}

Pterygium excision with the bare sclera technique was first described by Ombrain. ${ }^{22}$ It represents the most convenient and commonly used procedure all over the world. However it is accompanied by recurrence rate of $30-50 \% .{ }^{56}$ In our group of 15 patients the recurrence rate was much higher $(60 \%)$. Because of the increased recurrence rate, adjunctive treatment was necessary to achieve good results. Mitomycin is an antimetabolite with antiproliferative effect on cells showing the highest rate of mitosis by inhibiting DNA synthesis. It is produced by Streptomyces caesopitosus. The drug is also referred to as mitomycin $C$ to differentiate it from mitomycin A and B which under certain conditions are also produced by Streptomyces caesopitosus. Mitomycin C is present in a blueviolet crystalline powder and is soluble in water. Following reconstitution of the powder for topical use, mitomycin $0.4 \mathrm{mg} / \mathrm{ml}$ has a $\mathrm{pH}$ of 6-8, and is stable for 2 weeks when refrigerated at $2-8^{\circ} \mathrm{C}$. When used in topical form, our series of 17 eyes of 15 patients showed no recurrence at all - a $100 \%$ success rate. The minimum follow up period for these patients was 13 months. This is very significant as most of our recurrences in the first group occurred during the first 6 months (first case at 10 months). Our patients showed only exaggerated conjunctival injection with delayed wound healing for 3-4 weeks, but this settled down with no significant consequences.

We think this form of adjunctive therapy is superior in comparison with the other modes of treatment such as topical thiotepa drops, ${ }^{14}$ radiation, ${ }^{710}$ and laser treatment. ${ }^{12}$ Even compared with conjunctival autografts, this technique is simpler as it is performed only under local anaesthesia thus avoiding the risk of retrobulbar anaesthesia in young patients.

1 Duke-Elder WS. System of ophthalmology. Vol 8, Part 1. London: Henry Kimpton, 1965: 573-83.

Sandford-Smith J. Eye diseases in hot climates. Bristol: ELBS/ Wright, 1987: 104-5.

3 Pico G. Recurrent pterygium in corneal and external disease of the eye. In: Polack F, ed. First InterAmerican Symposium. the eye. In: Polack F, ed. First InterAmerican Sym

4 Van Den Brenk HAS. Results of prophylactic postoperative irradiation in 1300 cases of pterygium. Am $\mathcal{J}$ Roentgen 1968; 103: 723-33.

5 Fine $M$. Recurrent pterygium, mucous membrane grafts. In; Barragnce JJ, Binder PS, Buxton JN, et al, eds. Symposium on medical and surgical disease of the cornea. Transaction of the New Orleans Academy of Ophthalmology. St Louis: Mosby 1980: 533-40

6 Inster MS, Caldwell DR. Peripheral diseases (Terrien's and recurrent pterygium). In: Brightbill FS, ed. Corneal surgery theory, technique and tissue. St Louis: Mosby, 1986; 387-95.

7 Alaniz-Camino $F$. The use of postoperative beta radiation in the

8 De-Keizner RJW. Pterygium excision with or without postoperative irradiation, a double blind study. Doc Ophthalmol 1982; 52: 309-15.

9 Cooper JS. Postoperative irradiation of pterygia. Ten more years of experience. Radiology 1978; 128: 753-6.

10 Bahrassa F, Datta R. Postoperative beta radiation of pterygia. Int f Radiol Oncol Biol Phys 1983; 9: 679-84.

11 Tarr KH, Constable IJ. Late complications of pterygium treatment. BrF Ophthalmol 1980; 64: 496.

12 Boyd BF. Highlights of ophthalmology. Atlas and textbook of microsurgery and laser surgery. 30th Anniversary Panama, Republic of Panama: Highlights of Ophthalmology, 1984; R34-45.

13 Joselson GA, Muller P. Incidence of pterygium recurrence. Am 7 Ophthalmol 1966; 61: 891-3.

14 Langham ME. The inhibition of corneal vascularisation by triethylene thiophosphoramide. Am 7 Ophthalmol 1960; 49: (May Pt II) 25.

15 Meacham CT. Triethylene thiophosphoramide in the prevention of pterygium recurrence. Am $\mathcal{F}$ Ophthalmol 1962; 54: 751

16 Rock RL. Inhibition of corneal vascularisation by triethylene thiophosphoramide. Arch Ophthalmol 1963; 69: 330.

17 Kenyon KR, Wagner MD, Hettinger ME. Conjunctival autograft transplantation for advanced and recurrence pterygium. Ophthalmology 1985; 92: 1461-70.

18 Thoft RA. Conjunctival transplantation. Arch Ophthalmol 1977; 95: 1425-7.

19 Hayasaka S, Noda S, Yamamoto Y, Setogawa T. Postoperative instillation of low-dose mitomycin-C in the treatment of primary pterygium. Am f Ophthalmol 1988; 106: 715-8.

20 Singh G, Wilson MR, Foster S. Mitomycin eye drops as Singh G, Wilson MR, Foster S. Mitomycin eye drops as
treatment for pterygium. Ophthalmology 1988; 95: 813-21.

treatment for pterygium. Ophthalmology 1988; 95: 813-21. treatment of the pterygium by mitomycin-C instillation. treatment of the pterygium by mitom
Acta Soc Ophthalmol fpn 1963;67: 601.

22 Ombrain A. The surgical treatment of pterygium. $\mathrm{Br} \mathcal{J}$ Ophthalmol 1948; 32: 65. 